\title{
A Witness of Their Own Nation: On the Influence of Juan Andrés
}

\author{
Ryan Szpiech
}

Many have now heard the story of how, on 4 January 2007, the first Muslim to be elected to the United States congress - Democratic representative from Minnesota Keith Ellison - was sworn in, not without some controversy. As is the custom, public servants are allowed, in the non-official presentation for the media leading up to the actual swearing-in ceremony in the House of Representatives itself, to place their hand on the Bible while vowing to do their duty. Since Ellison is a convert to Islam, he asked if he could use the Qurān rather than the Bible, and he was allowed to use no less than the personal copy of the Qurān in English translation that once belonged to Thomas Jefferson, a copy that, after surviving multiple fires in the Capitol, now resides in the Library of Congress. This use of the Qurān caused considerable controversy, spurring conservative author and pundit Dennis Prager to declare in an editorial that 'America, not Keith Ellison, decides what book a congressman takes his oath on.'. Although this remark was denounced by the Anti-Defamation League as 'intolerant, misinformed, and downright un-American', Prager's views found some sympathetic ears, and a chain email started circulating at this time alleging that us president Barak Obama had similarly been sworn in to the presidency on a Qurān instead of a Bible, and that he was actually a clandestine Muslim. ${ }^{2}$

While this story and its fallout are now well known, what is not commonly known is that Jefferson's Qurān, a 1764 printing of an English translation made

1 Dennis Praeger, 'America, Not Keith Ellison, Decides What Book a Congressman Takes His Oath On', Townhall.com 28 November 2006, <http://townhall.com/columnists/dennisprager/2006/11/28/america,_not_keith_ellison,_decides_what_book_a_congressman_takes_his_ oath_on> [accessed o1 November 2015].

2 'ADL Statement on Dennis Prager's Attack on Muslim Congressman for Taking Oath of Office on Koran', 1 December 2006, <http://archive.adl.org/nr/exeres/efa3baa7-9817-40d1-8d2c6oa449e3d717,ob1623ca-d5a4-465d-a369-df6e8679cdge,frameless.html $>$. On the chain mail and claims about Obama, see Angie D. Holan, 'Obama used a Koran? No, he Didn't', Politifact. com, 20 December 2007, <http://www.politifact.com/truth-o-meter/article/2007/dec/20/ chain-email-gets-obama-religion-wrong $>$ [accessed o1 November 2015].

(C) RYAN SZPIECH, 2016 | DOI 10.1163/9789004324329_008

This is an open access chapter distributed under the terms of the CC-BY-NC-ND License. 
by George Sale in 1734, contains references to Christian readers of the Qurān that reach far back into the past, even as far as sixteenth-century Iberia. In his prologue, Sale refers directly to one 'Johannes Andraes, a native of Xativa, in the kingdom of Valencia, who from a Mohammedan doctor became a Christian priest, translated not only the Koran but also its glosses and the seven books of the sonna, $[s i c]$ out of Arabic into the Arragonian tongue.' ${ }^{3}$ This 'Johannes Andraes' is none other than Juan Andrés, the name given as the author of the anti-Muslim treatise Confusión o confutación de la secta mahomética y del alcorán (Confusion or Confutation of the Muhammadan Sect and of the Qurān), published in Valencia in 1515. Although we know little about who Juan Andrés was, the fact that George Sale mentions his name and text in the eighteenth century is not an anomaly, for he was cited by a continuous stream of Christian writers about Islam from the sixteenth century all the way to the end of the eighteenth, and even on occasion in the nineteenth and twentieth, not only in Spain but throughout Europe and the United States.

In this essay, I will first explore what little is known about Juan Andrés' identity. I will then trace out some of the channels of his influence, explaining the model of testimony within a conversion narrative that he made use of, and considering in particular the influence of Juan Andrés' use of original Arabic texts. By sketching out the reach of his influence in subsequent writing, I will suggest that Juan Andrés, a mysterious, poorly understood figure, served as a unique vector of transmission of medieval polemical writing to the early modern and modern world, and that his representation of the Qur'ān, while not the most accurate or the most exhaustive of Iberian sources, was by far the longest lived and the most influential for centuries after.

\section{In Search of Juan Andrés}

We know very little for certain about the life of Juan Andrés, and most of what little we think we know has come from Juan's prologue to the Confusión, where he states that he was born a Muslim in the city of Xàtiva, near Valencia:

I was born and instructed and taught in the sect of Muhammad by 'Abdallāh my biological father, who was a faqīh [religious jurist] for the same city. After his death I succeeded him in his office of faqih, in which

3 George Sale, The Koran: Commonly Called the Alcoran of Mohammed, Translated into English Immediately from the Original Arabic (London: L. Hawes, W. Clarke, R. Collins and T. Wilcox, 1764), p. xi. 
I was lost for a long time and had veered off the path of truth, until the year of 1487 , when I found myself present in the main church of the illustrious city of Valencia on the day of Our Lady in August, when the very reverend and no less learned Master Marqués was preaching. Suddenly, the shining rays of divine light ... removed and cleared the shadows of my understanding, and then opened the eyes of my soul. ${ }^{4}$

Despite the concreteness of this statement, giving Juan Andrés' city of birth, his father's name, and the day, year, and place of his alleged conversion, little to nothing is known for certain who he was. The name of one 'Juan Andrés' appears in a list of canons of the Cathedral of Granada from around 1516, but the list gives no further information to connect this name with certainty to the author of the Confusión. ${ }^{5}$ It has, despite repeated scholarly efforts, proven extremely difficult to verify his identity - or even confirm Juan Andrés' very existence - with certainty.

One logical place to search for information about Juan Andrés is in the circumstances of his work's publication. In the same year (1515) as his widely popular Confusión was published by the Valencian publishing house of Juan Jofré, another text, attributed to the same name of 'Juan Andrés', was published by the same house: the Sumario breve de la práctica de la arithmética de todo el curso de larte mercantivol bien declarado, el qual se llama maestro de cuento (Brief Summary of the Practice of Arithmetic in the Course of the Mercantile Art, which is called the Master of Accounting). ${ }^{6}$ Although García-Arenal and

4 'Fuy nacido y instruydo y enseñado en la secta mahomética por Abdalla, mi natural padre, alfaquí de la dicha ciudad, por cuya muerte succedí yo en su oficio de alfaquí, en que mucho tiempo estuve perdido y desviado de la verdad, fasta que en el año de 1487 predicando en la yglesia mayor de la insigne ciudad de Valencia, hallándome yo presente en día de Nuestra Señora de Agosto, el muy reverendo y no menos docto varón maestre Marqués, a desora los resplandescientes rayos de la divinal luz ... removieron y esclarescieron las tenieblas de mi entendimiento y luego se me abrieron los ojos de la ánima'; Juan Andrés, Confusión o confutación de la secta Mahomética y del Alcorán, (ed.) Elisa Ruiz García and María Isabel GarcíaMonge (Mérida: Editora Regional de Extremadura, 2003), p. 89. Copies of this text survive in the Biblioteca Civica Queriniana in Brescia and in the British Library.

5 Rafael Marín López, El cabildo de la catedral de Granada en el siglo XVI (Granada: Universidad de Granada, 1998), p. 438.

6 Juan Andrés, Sumario breve de la practica de la arithmetica de todo el curso de larte mercantivol bien declarado, el qual se llama maestro de cuento (Valencia: Juan Jofré, 1515; Valencia: Vicent García Editores, 1999). On this text, see Vicente L. Salavert Fabiani, 'Introducción a la historia de la aritmética práctica en la Corona de Aragón en el siglo xvi', Acta Hispanica ad Medicinae Scientarumque Historiam Illustrandam, 10 (1990): pp. 63-91, at pp. 70-72; and Natalie Zemon Davis, Trickster Travels: A Sixteenth-Century Muslim Between Worlds (New York: Hill and Wang, 
Starczewska have suggested that these two works might not be by the same author, I believe that this question must be analyzed in greater depth in light of the multiple editions of the work. ${ }^{7}$ While one group of copies of this work (which I will call Sumario ${ }_{1}$ ) contain a prologue dedicating the work to Serafín Centelles y Urrea, Count of Oliva (1460-1536), a second group (which I will call Sumario $_{2}$, although it is not actually clear if it was the first or second of the two), contains a different prologue dedicating the work to Martín García Puyazuelo (ca. 1441-1521), bishop of Barcelona. A different title page, depicting above the title the heraldic arms of each figure, respectively, accompanies the two editions. ${ }^{8}$ While the two groups are exactly the same in all other respects, including the colophon dating the printing to 30 August 1515 (I will call the text shared by both printings simply Sumario), the alternate prologue in the Sumario $_{2}$ connects this printing to the Confusión, because Martín García is mentioned explicitly in the prologue to the latter work as one of the leaders who oversaw and guided the young Juan Andrés in his polemical projects after his conversion. Based on his statements in the Confusión, Juan Andrés was, after his conversion, called by Fernando and Isabel, the Catholic Monarchs, to Granada, where he claims to have become a canon and to have 'preach[ed] to the moors of that kingdom that their Highnesses had conquered where, by my preaching and the will of God, who wanted it so, an infinite number of moors (infinita morisma), by rejecting Muhammad, converted to Christ'. ${ }^{9}$ By these claims, Juan Andrés situates himself with the Christianization of the city that took place in the 1490s under the auspices of Hieronymite friar Hernando de Talavera, who was archbishop of Granada beginning in 1492, rather than under

2006), p. 336 n. 8. I am grateful to Professor Davis for discussing Juan Andrés and the Sumario with me - it was her suggestion and encouragement that led me to explore the connection between the Sumario and the Confusión in more detail.

7 Mercedes García-Arenal and Katarzyna K. Starczewska, 'The Law of Abraham the Catholic: Juan Gabriel as Qur'ān Translator for Martín de Figuerola and Egidio da Viterbo', Al-Qanțara, 35 (2014): pp. 409-59, at p. 433 n. 77.

8 According to the colophons of the Sumario and Confusión, the former was written in Zaragoza in 1514 and published in Valencia on 30 August 1515 (Sumario, fol. 144r), while the latter was published on 13 November 1515 (fol. 88v, Confusión, p. 230). Both the Sumario and the Confusión contain the same woodcut of La Virgen del Pilar (Sumario, fol. 1v; Confusión, fol. 5v). I am grateful to Manuel Montoza Coca for sharing images of the prologue to Martín García in Sumario $_{2}$ with me. Copies of this alternate edition survive in the Biblioteca Lambert Mata in Girona and in the University of London (Senate House).

9 'Fui llamado por los más cathólicos príncipes, el rey don Fernando y la reyna doña Ysabel, para que fuesse en Granada a predicar a los moros de aquel reyno que sus Altezas avían conquistado, donde por mi predicación y voluntad de Dios, que así lo quería, infinita morisma, renegando a Mahoma, a Cristo se convertió'; Juan Andrés, Confusión, p. 90. 
the harsh methods imposed by Cardinal Cisneros at the Catholic Monarchs' request, beginning in late 1499. Talavera insisted on upholding the terms of the capitulations of Granada from 1492, which stipulated that coercion would not be used to obtain conversion, and he thus followed a notably Pauline method of evangelization based on preaching, undertaken with the support of converted Muslims and local faqīhs, and made it possible for Muslims to make confession in Arabic. ${ }^{10}$ His evangelical policies were largely cast aside after 1499 and by 1502, the capitulations of 1492 had been revoked and all Muslims of Castile were compelled to accept baptism.

Around 1500, not surprisingly, Juan was called by Queen Isabel to leave Granada and continue his missionizing in Aragon, where policies like those of Cisneros had not yet taken root, but his evangelical work there was cut short by the death of the Queen in 1504:

Giving up then that goal [of missionizing in Aragon], I turned - in order to keep busy - to translate from Arabic into the Aragonese language the entire law of the Moors, called the Qur'ann, with its glosses and the seven [sic] books of the Sunna. I was also moved to do this by the order of the very reverend master Martín García, bishop of Barcelona and inquisitor of Aragon, and my patron and lord, so that in the charge which he had from their Highnesses to preach to the moors, he could confuse and conquer them with the authorities of their own law, which it would be difficult for him to do without that work of mine.11

Knowing as we do that Martín García was a canon in Zaragoza in the 1480 , confessor of the Queen after 1487, inquisitor in Zaragoza and Tarazona after 1492, preacher in Granada after 1500 and bishop of Barcelona by 1515, it is possible to construct a rough chronology of Juan Andrés' movements in relation to him. ${ }^{12}$

10 Mercedes García-Arenal, 'The Religious Identity of the Arabic Language and the Affair of the Lead Books of the Sacromonte of Granada', Arabica, $5^{6}$ (2009): pp. 495-528, esp. pp. 501-02.

'Cessando, pues, por entonces aquel fin, yo, por no estar ocioso, convertime a trasladar de arávigo en lengua aragonesa toda la ley de los moros, digo el Alcorán con sus glosas y los siete (sic) libros de la Çuna; movido también a esto por mandado del muy reverendo señor maestre Martín García, obispo de Barçelona y inquisidor de Aragón, mi patrón y mi señor, porque en el cargo que tenía de sus Altezas de predicar a los moros podiesse, con las auctoridades de su misma ley, confundirlos y vencerlos, lo que sin aquel trabajo mío con difficultad podiera hazer'; Juan Andrés, Confusión, p. 91. example, the now-dated José Ribera Florit, 'La polémica cristiano-musulmana en los 
Apart from the link between the Sumario and the Confusión provided by the figure of Martín García, however, the former text yields only limited information about the author's religious activities. Unlike the Confusión, the Sumario offers virtually no evidence of the polemical perspective of a Muslim convert to Christianity, apart from two chapters mentioning Islam and Muslims (one mentioning 'Morisco multiplication, which is in the practice [modo de uso] of the Moors,' and another naming 'a man who was captive in the land of the Moors, whose three sons went to rescue him'). ${ }^{13}$ Neither of these sections, however, contains any polemical content, although the author does speak with some knowledge about traditions beyond Christianity and praises the Muslim method of accounting as 'the best and most certain although it is not used by Christian merchants, because they do not know it.'.14 The prologue to the Sumario ${ }_{2}$ dedicated to Martín García likewise contains nothing of a polemical anti-Muslim nature.

Thus while circumstantial evidence does connect the Sumario and the Confusión as the work of the same author and does seem to confirm that Juan Andrés actually did exist, they offer very little to help identify who Juan Andrés might be, beyond his identification in the Sumario as 'Juan Andrés, unworthy and humble among clerics' and the statement that the work was written in Zaragoza in $1514 \cdot{ }^{15} \mathrm{He}$ mentions future plans of writing 'a treatise that we want to make about the great art, that is, the art of algebra', a work that, as far as we know, did not get written. ${ }^{16}$ In the prologue of Sumario $_{2}$ dedicated to Martín García, Juan Andrés mentions the former's help in 'any work, as much of arithmetic and practical [mathematics] as in support of the holy Catholic faith, that I might compose', possibly alluding to his Confusión, which he spe-

Sermones del maestro inquisidor don Martín García', BA thesis. (Barcelona: Universidad de Barcelona, 1967), 26-32; Joseph Antonio de Hebrera, Vida prodigiosa del ilustrísimo y venerable D. Martín García, obispo de Barcelona, hijo de la fidelíssima y antigua villa de Caspe (Zaragoza: Domingo Gascón, 1700); and most recently, Manuel Montoza Coca, 'Edición, traducción y comentario de los sermones del I-V de Don Martín García', MA Final Diss., (Barcelona: Universitat Autònoma, 2013), pp. 7-10.

13 'La segunda manera se llama multiplicar morisco que es al modo de uso de los moros'; Sumario, fol. 31r. 'un hombre que estaua catiuo en tierra de moros y fueron tres fijos suyos para a rescatarlo'; Sumario, fol. 133v.

'la mas sana y mas segura encara que entre los mercaders cristianos no se usa porque no la saben'; Sumario, fol. 31 r.

'Juan Andrés indigno y humilde entre los clerigos'; Sumario, fol. 4r. On the composition in Zaragoza, see Sumario, fol. 4r, fol. 143r-v. 
cifically identifies as a work written under García's direction. ${ }^{17}$ He states in the prologue of Sumario ${ }_{1}$ dedicated to the Count of Oliva that, "I knew your Lordship since your childhood', and given that the Count was born around 1460, this statement implies that Juan Andrés may have been born around that time also, or perhaps a little before, a dating that corresponds roughly to Juan Andrés' statement that he embraced Christianity around 1487, then being already old enough to have replaced his father as faqīh of Xàtiva after his death. ${ }^{18}$

Despite these bits of information that might be used to piece together a biography of Juan Andrés, the actual content of the Confusion, which offers the most autobiographical information about the author in the prologue, presents a significant problem of interpretation. While Juan Andrés claims, on the one hand, to be from the important and populous Muslim community of Xàtiva and to have been a jurist and teacher who was trained by his father, the Confusión contains erroneous statements and confused arguments that would be unexpected from even a moderately educated Muslim. For example, Juan Andrés states that the word 'Qur'ān' means 'gathering of chapters or psalms and verses', which is not only technically not true - the word 'Qur'ān' means 'a recitation' or 'a reading,' whereas a gathering of leaves of the Qur'ān is a muṣhaf, a kurrāsa, or possibly a juz', and an anthology of verses is a majmǘa. Also, Juan's claim seems to suggest that he saw the Qurān as primarily a written book rather than an oral recitation, which itself is a puzzling claim for an alleged religious leader to posit. ${ }^{19}$ In the Confusión, Juan follows the description of the Qur'ân common in North Africa of dividing the text into four 'books', each containing a variable number of 'chapters'. However, he also asserts that the Qur'ān contains a total of '211 chapters' (rather than the traditional number of 114 suras), including 175 chapters in the fourth 'book'. According to his description, this book ought to include all material beginning at the sura Sad (traditionally sura 38 ), and should thus contain 76 suras, not 175. Juan Andrés' numbering and count do not match any known distribution.

Juan Andrés also seems to get some basic details wrong in his account of Muslim history. He states that the Qur'ān 'was begun in Mecca in the year in

17 'qualquiere obra asi de arithmetica y pratica como en favor dela santa fe catholica yo composiere'; Sumario ${ }_{2}$, fol. 2 r. lates that Juan Andrés must have been born by 1467 or before; Juan Andrés, Confusión, p. 41 n. 60.

19 'Alcoran quiere dezir congregación de capítulos o psalmos y versos'; Juan Andrés, Confusión, p. 118. 
which Muhammad was forty years old, which was the year 630 of our Lord'.20 Even if we take this as a scribal or typographical error (confusing ' $\mathrm{xxx}$ ' with ' $\mathrm{x}$ ' to read 630 rather than the correct year, 610), the other chronological statements made by Juan Andrés confuse things further. Juan Andrés claims Muhammad revealed the Qur'ān for twenty-three years, not twenty-two, and he elaborates that he was in Mecca for 'ten years', not twelve (610-22) and was then in Medina for 'thirteen years', not ten $(622-32)$ and not twelve. ${ }^{21}$ He states that the first three Rashidun Caliphs were in-laws of the Prophet, when in reality only the first, Abū Bakr, and the fourth, 'Alī, were in-laws (father-in-law and son-in-law, respectively). He also states that 'Uthmān was killed 'by a sword thrown by the hands of 'Alī ... which was poisoned by the hands of 'Aisha,',22 when in reality 'Uthmān was killed by others and it was 'Alī who was killed with a poisoned sword, having nothing to do with 'Aisha (who by all views, Sunnī and Shìte, was often in conflict with 'Alī and would, one assumes, never have collaborated with him).

Juan Andrés seems no less confused about the standard texts of Islamic tradition. He claims that the standard books of hadith (traditions about the Prophet) were compiled by six sages working as a group, when in reality the canonical books of hadith were compiled in different decades and in different places. ${ }^{23} \mathrm{He}$ further claims that Abu Hurayra (d. 681) collaborated with other hadith compilers when in reality he died well over a century before all the other authors mentioned by Juan Andrés (Bukhārī, Muslim, Abū Dāwūd, Tirmidhī, Nasā̄î) were born. He claims that Muhammad's mother 'Ymina' (Āmina) 'morió dos años después que Mahoma nasció'. The early biographies of the Prophet (Sira Rasūl Alläh), most representative of which is that of Ibn Ishāa (d. 76o/61), state clearly that Muhammad's mother lived until he was five or six years of age, after which time he went to live with his grandfather. ${ }^{24}$ Such

20 'Fue començado en Mequa en el año que Mahoma uvo quarenta años, que fue año seyscientos xxx de Nuestro Señor'; Juan Andrés, Confusión, p. 120.

21 Juan Andrés, Confusión, p. 120, p. 125. Juan Gabriel makes a similar error in the Latin Qurān of Egidio da Viterbo. See the gloss on Qurān 2:49, which states, 'Et Alcoran Machomae fuit in principio indigestum quod diuersis temporibus recepisse fabulantur e caelo spatio uiginti trium annorum, quorum decem accepit in Mecha et tredecim in Medina'. My sincere thanks to K. Starczewska for pointing this out to me and for sharing the text. Juan Andrés, Confusión, p. 126; also 'Hozmen, tercero algalifa ... fue muerto por una espada tirada por las manos de Alí ... la qual espada fue metzinada por manos de Axa'; Juan Andrés, Confusión, p. 228.

23 Juan Andrés, Confusión, p. 131.

24 Juan Andrés, Confusión, p. 98; Ibn Isḥāq, The Life of Muḥammad: A Translation of Ishạa's Sīrat Rasūl Allāh, (trans.) A. Guillaume (1945; repr. Karachi: Oxford University Press, 2004), states plainly that, 'he was six years old'; p. 73. 
a fact would have been common knowledge even for slightly educated Muslims, and the fact that Juan Andrés mentions the Sirra by name in the discussion suggests that he consulted it and his statement thus represents an even more obvious error. One could add many more examples to this list of apparent errors and confused ideas.

Such statements make it impossible to accept as true Juan Andrés' claim in the Confusion that he translated 'from Arabic into the Aragonese language the entire law of the Moors, that is the Qurann, along with its commentaries, and the seven books of the Sunah., ${ }^{25}$ No text of Juan Andrés' Qurān translation has survived, calling his claim further into doubt. ${ }^{26}$ Juan Andrés does not make clear just which among the abundant tafsir commentaries he is referring to here, but his reference to 'seven books' constitutes a confused mention of the Kutub al-sitta, 'six books' of hadith sayings about the Prophet Muhammad, which all together make up many thousands of pages. (Juan Andrés elsewhere refers to 'six' collections, in which he includes Abū Hurayra, whom other hadìth authors do actually name although he wrote no known work). The prospect that Juan Andrés successfully made a translation of the entire Qur'ān as well as thousands of pages of hadith and hundreds or thousands more of tafsir is in itself extremely difficult if not impossible to believe, and the fact that not a single page of Juan's alleged translations has survived apart from the content of Juan's own Confusión strains credulity even more. Juan Andrés may have made translations of selected passages, perhaps for use by Martín García and his followers, but certainly not 'the entire law of the Moors', whatever this might be thought to consist of.

Juan Andrés' exaggerated, erroneous or unorthodox statements undermine the possibility that he was an intellectual leader in Xàtiva before his conversion. On the one hand, Harvey has argued that among Moriscos in Aragon, al-faqīh, the title Juan Andrés gives himself, does not necessarily mean 'jurist' or intellectual, noting that 'in Valencia the alfaqui might be little more than a

25 'Convertime a trasladar de arávigo en lengua aragonesa toda la ley de los moros, digo el Alcorán con sus glosas y los siete (sic) libros de la Çuna'; p. 91.

26 Then again, if such a Qurān translation did once exist, it would not be the first of the period to go missing. For example, nothing of Juan de Segovia and 'Isa ibn Jabïr's multilingual Qur'ān translation has survived except for the prologue. For the text of the surviving prologue, see José Martínez Gázquez, 'El prólogo de Juan de Segobia al Corán (Qur'ān) trilingüe (1456)', Mittellateinisches Jahrbuch, 38.1-2 (2003): pp. 389-410; and the entry 'Juan de Segovia', in Christian-Muslim Relations: A Bibliographical History, Vol.V (1350-1500), (ed.) David Thomas and Alex Mallett (Leiden: Brill, 2013), pp. 429-42, esp. pp. $440-42$. 
local schoolmaster and teacher,,27 although the exact importance of the position Juan Andrés claims for himself is not at all clear. On the other hand, contemporary references to the faqīh of Xàtiva from around 1492 speak of the position as if it carried a good degree of learning and influence. ${ }^{28}$ Juan Andrés' clumsy and often confused handling of Muslim sources and tradition suggests that he was, at best, a literate Muslim of rather moderate learning, or that what he presents in the Confusión is distorted to fit the extreme rhetoric of polemical writing and does not accurately reflect the author's true knowledge.

Taking the Sumario and the Confusión together as the work of a single author, we might speculate that Juan Andrés was born a Muslim in Xàtiva around 1460 , received a modest education (probably in part from his father) in Islamic tradition and the Arabic language, was trained as an accountant before his conversion in Valencia around 1487, worked in Granada sometime between 1492-99, preaching and translating texts of Islamic tradition in the missionary campaigns of Archbishop Talavera, and found himself in Zaragoza in the early sixteenth century, probably working as an accountant. There he participated in the intellectual circle of Martín García, working under García's guidance to contribute information about Islam for use in missionizing and polemics. $\mathrm{He}$ was probably in Valencia in 1515 and in Granada in $1516 .{ }^{29}$ Nothing is known of his death but we might speculate that it took place in Zaragoza or Granada before 1530 .

Yet the factuality of this biographical sketch cannot be confirmed, and it fails to address the important problems surrounding Juan Andrés' knowledge and the lack of solid information about his life from any other source. Another possibility that must also be entertained, therefore, is that Juan Andrés was a partly real, partly invented personage. Archival information corroborating the story presented by Juan Andrés in the Confusión remains to be found in the Archives of Valencia or the crown of Aragón. This absence of documentation is highly suspicious, especially considering the importance of the position that Juan Andrés claims to have had, the existence of other archival documents discussing the religious intelligentsia of Xàtiva during the very years Juan

27 Leonard P. Harvey, Islamic Spain, 1250 to 1500 (Chicago: University of Chicago Press, 1990), p. 128.

28 Mark D. Meyerson, The Muslims of Valencia in the Age of Fernando and Isabel: Between Coexistence and Crusade (Berkeley: University of California Press, 1990), notes 'The primary role of the faqi was that of jurisconsult, acting either as counsellor or as arbitrator in litigations between Muslims ... the faqi also taught in the local school, a task for which his years of study had well prepared him'; p. 265.

29 See also the biographical sketch provided by Elisa Ruiz García in her edition of the Confusión, pp. 37-41. 
Andrés' story was supposed to have taken place, and the mention in the archive of Valencia of other, less prominent converts. ${ }^{30}$ If other converts are mentioned, why not Juan Andrés? If the activity of the alfaquí is discussed in some detail, where is Juan Andrés' story? At the same time, there are details about the religious history of Xàtiva that vaguely echo the details of Juan Andrés' story without confirming it. There is, for example, mention of at least one alfaquí of Xàtiva named Abdalla in the early 1490s, not a convert but a former captive from Tunis. ${ }^{31}$ Perhaps the 'Juan Andrés' associated with Martín García and Martín de Figuerola and named as a canon of the Cathedral of Granada was a real but unremarkable convert. Perhaps also his story was embellished with the names of plausibly real characters (such as 'Abdalla') from the real history of Xàtiva and his book was composed by a group rather than a single person. ${ }^{32}$ Such embellishment could be easily explained as a means pursued by Martín García and those of his circle to legitimately claim that the Confusión was based on 'authorities of their own law' and that Moriscos ought to follow

30 See the documents and examples mentioned by Meyerson, The Muslims of Valencia, pp. $231^{-}-32$ and p. 337 n. 38 .

On references to the choosing of an alfaquí in Xàtiva in 1492 (suspiciously named 'Abdalla', as Juan Andrés claims his father was named), Mark Meyerson notes that 'The career of Abdalla also demonstrates that Mudéjares on the whole respected and heeded the opinions of learned and holy men. Abdalla was known by Muslims throughout the kingdom and was reputed to lead the life of a saint. The qadi of Xàtiva, the kingdom's largest morería, related why he and the aljama wished to make Abdalla their jurist. Abdalla, the qadi pointed out, "is a very good Moor and ... leader of prayers (oracioner)", so much so that after the death of the former faqi of Xàtiva, Abdalla, owing to his "good fame, life and knowledge", was the unanimous choice to succeed him. Clearly, the prestige of Abdalla, a foreigner and technically a slave, and of men like him in the eyes of the Mudejar community, rested neither on wealth nor on family backing; rather their status and influence, both local and, in the case of Abdalla, kingdom-wide, derived from their knowledge of religious and legal tradition and from the holiness of their lives'; Meyerson, The Muslims of Valencia, p. 267. Documents related to Abdalla, including a trial of his activities in aiding escaped captives, are found in the ARV, B1431: fols. 344r-375r.

The theory that the text in the Confusion was the product of various levels of intervention (author, copyist, typesetter) was suggested by Everette Larson, 'A Study of the Confusión de la secta mahomática of Juan Andrés', PhD Diss., (Washington DC: Catholic University of America, 1981), p. 26. Mercedes García-Arenal and Katarzyna Starczewska have recently suggested that the work may be the product of a team of authors as well. See García-Arenal and Starczewska, 'The Law of Abraham', who propose 'that the text attributed to Juan Andrés was not in its entirety authored by him; at the very least, we can argue that his text was created in the circle of Martín García and was put together by different authors and in different hands', p. 436. I am grateful to the authors for sharing the text with me ahead of its publication. 
this 'witness of their own nation'. ${ }^{33}$ One can imagine that a few decades after the alleged events, such details about the Muslims of Xàtiva might have seemed vaguely plausible but were too distant to be gainsaid with any confidence. In this way, the real Juan Andrés might have been transformed with a mixture of fact and literary topoi to become the authorial persona presented in the prologue of the Confusión. On the other hand, there is no reason to postulate a similar case of multiple or pseudonymous authorship for the Sumario, which does not speak about events of the past in a testimonial form and has no rhetorical or polemical imperative similar to that in the Confusión.

\section{The Dissemination of Juan Andrés: The Case of the Death of Solomon (Qur'ān 34,14)}

Although Juan Andrés' alleged translation of 'the entire law of the Moors' has not survived, Juan Andrés' Confusión contains abundant citations, both of qur'ānic suras written in Arabic transliterated into Latin characters an given along with Castilian translations, as well as hadith passages given in translation. These citations are an important key to tracing the wide impact of Juan Andrés' writing. Notices of three subsequent Castilian editions following the 1515 printing exist (Valencia, 1519; Seville, 1537; Granada, 1560), although no known copies survive from these later printings. ${ }^{34}$ Apart from these missing editions, we can trace Juan Andrés' impact in the peninsula by tracing the appearance of his book in library lists. For example, copies of Juan Andrés' book were held in the library of Joan de Borja i Enríquez, third Duke of Gandía. ${ }^{35}$ Bernard Ducharme has also pointed to a document from $155^{1}$ describing how Inquisitor Gregorio de Miranda confiscated copies of Pérez de Chinchón and Juan Andrés from some students attempting to use them for polemical arguments with Moriscos,

33 Juan Andrés, Confusión, pp. 91-92.

34 These editions are summarized by Ruiz García, Confusión, p. 54, n. 82. Manuel Traggia de Santo Tomás de Aquino describes a copy of the 1519 printing of Juan Andrés' work in the library of Francisco Fabián y Fuero, bishop of Puebla in Mexico and then later Valencia. 'Es indubitable, haberse impreso en la ciudad de Valencia en castellano, año 1519. Y efectivamente existe en la Biblioteca del Palacio del Sr. Arzobispo de Valencia, D. Francisco Fabián y Fuero, Estante 34, let. E, donde equivocado el rótulo del tronco, yacía en el olvido'. See Manuel Traggia de Santo Tomás de Aquino, Verdadero carácter de Mahoma y de su religión (Valencia: Francisco Burguete, 1793), pp. 37-38.

35 José Luis Pastor Zapata, 'La biblioteca de don Juan de Borja, tercer duque de Gandía (m.1543)', Archivum Historicum Societatis Jesus, 61 (1992): pp. 275-308, esp. pp. 290-94. 
on the grounds that the texts contained religious polemic in Romance and, more importantly in the case of Juan Andrés, they cited Arabic. ${ }^{36}$

We can also follow Juan Andrés' impact through a number of other antiIslamic books written in Latin or Castilian in the sixteenth and seventeenth centuries, all of which made direct use of Juan Andrés' Confusión: for example, the sermons of Martín García, published in Zaragoza in $15^{20} ;^{37}$ the Antialcorano of Bernardo Pérez de Chinchón from $153^{2} ; 3$ and the Confutación del alcorány secta mahometana, sacado de sus proprios libros, y dela vida del mesmo Mahoma, by Lope de Obregón, priest in Ávila in the mid-sixteenth century, from $1555 \cdot{ }^{39}$ Juan Andrés' influence does not stop with the Expulsion of the Moriscos around 16og. In the seventeenth century, the Confusión was cited by the Jesuit Tirso González de Santalla in his Manuductio ad conversionem mahumetanorum (1687) and by Manuel Sanz, Spanish Jesuit in Malta, in his Tratado breve contra la secta Mahometana (1693). Even a century later, the Discalced Carmelite Manuel Traggia de Santo Tomás de Aquino drew heavily from Juan Andrés in his Verdadero carácter de Mahoma y de su religión (1794), naming or citing him at length over forty times. ${ }^{40}$ Juan Andrés' citations of the Qur'ān -

36 Archivo Histórico Nacional, AHN, Inquisición, book 911, fol. 17v, referenced in Ricardo García Cárcel, Herejía y sociedad en el siglo XVI, la Inquisición en Valencia 1530-1609 (Barcelona: Península, 1980), p. 237. See Bernard Duchesne, 'De Talavera a Ramírez de Haro. Actores y representaciones de la evangelización de los mudéjares y moriscos en Granada, Zaragoza y Valencia (1492-1545)', in De la tierra al cielo. Líneas de investigaciones en Historia Moderna, (coord.) Eliseo Serrano (Zaragoza: Institución Fernando el Católico, 2013), p. 44, n. 16.

37 Sermones eminentissimi totiusque Barchinonensis gregis tutatoris acerrimi necnon immarcessibilis sacre theologie paludamento insigniti Martini Garsie (Zaragoza: Jorge Coci, [1520]). Beyond the study of Ribera Florit, 'La polémica cristiano-musulmana', see also Sebastián Cirac Estopañán, 'Los sermones de don Martín García obispo de Barcelona sobre los Reyes católicos', Publicaciones de la Universidad de Barcelona, 33 (1955): pp. 1-94; reprinted under same title (Zaragoza: La Académica, 1956); and Montoza Coca, 'Edición, traducción y comentario'. Montoza Coca is currently preparing an edition of García's sermons.

38 Bernardo Pérez de Chinchón, Libro llamado Antialcorano, que quiere dezir contra el alcoran de Mahoma (Valencia: Juan Jofré, 1532); edited as Antialcorano. Diálogos cristianos. Conversión y evangelización de Moriscos, (ed.) Francisco Pons Fuster (Alicante: Universidad de Alicante, 2000). See, for example, sermon 15.

39 Lope de Obregón, Confutación del alcorán y secta mahometana, sacado de sus propios libros y de la vida del mesmo Mahoma (Granada: n.p, 1555), fol. 2r.

40 Tirso González de Santalla, Manuductio ad conversionem mahumetanorum (Madrid: Juan de Goyeneche, 1687), vol. 2, pp. 8, 11, 16, 42, 395, 405, and others; Manuel Sanz, Tratado breve contra la secta mahometana ([Catania, 1691] Seville: Lucas Martín, 1693), p. 4, p. 60. On Manuel Traggia de Santo Tomás de Aquino's Verdadero carácter, see above, n. 31. 
both his Castilian translations and sometimes his transliterations of Arabic - were repeated directly by Pérez de Chinchón, Lope de Obregón, Johannes Maurus, Vicente Ximeno, ${ }^{41}$ and Manuel Sanz (who even quotes all of Juan Andrés' second chapter from the Confusión), and were translated into Latin by Martín García and González de Santalla.

One concrete example of Juan Andrés' influence on these subsequent texts can be found by tracing the copying and repeated references to one of Juan Andrés' many Qur'ān citations, that of Qur'ān 34:14, a reference to the death of Solomon, which Juan Andrés cites in chapter five of the Confusión. Juan Andrés begins the chapter by first citing Qur'ān 27,17-44 (which he numbers as 'book three, chapter nine'), in which an ant warns its fellows to take cover from the approach of Solomon's army, which caused Solomon to laugh. ${ }^{42}$ This story is linked to what Juan Andrés calls 'book three, chapter fourteen' (actually Qurān 34,14; note that this comes seven books after the former citation, not five), which Juan Andrés cites first in transliterated Arabic. The story that Juan Andrés discusses involves a short verse recounting a legend about Solomon's death, claiming that he died leaning on his staff and the Jinn, whom he had imprisoned, did not realize it until a däbbat al-ardi (creature of the earth) bored through his staff and he fell. The original verse to which Juan Andrés refers reads: 'When we decreed his [Solomon's] death, it was but a crawling creature of earth which indicated to them he was dead, as it gnawed his staff. When he fell, the Jinn realised that, had they known the Unseen, they would not have lasted in their abasing torment. ${ }^{43}$ Juan Andrés renders this fairly literally but makes some small changes, describing how the death of Solomon was not revealed to the Jinn (demonios) except by cause of a worm (gusano) that ate the staff of Solomon himself, for which reason Solomon fell to the ground and the Jinn knew what they had not known up to then.. ${ }^{44}$ Juan Andrés then adds to his translation the following commentary:

41 On the Moroccan-Dutch figure Johannes Maurus and his use of Juan Andrés, see Chapter 8 in this volume by Gerard A. Wiegers. On Ximeno's references to Juan Andrés in the eighteenth century, see Chapter 7 by Teresa Soto and Katarzyna K. Starczewska.

42 Juan Andrés, Confusión, pp. 151-52.

43 The Qurāan, (trans.) Tarif Khalidi (New York: Penguin Books, 2009), p. 347. For another discussion of the translation of this verse in other contemporary writing, see Chapter 5 by Pier Mattia Tommasino in this volume.

'Cómo la muerte de Salomón no fuera revelada a los demonios sino por causa del gusano que comió la vara del mesmo Salomón, por la qual causa cayó Salomón en el suelo y supieron los demonios lo que fasta allí no supieron'; Juan Andrés, Confusión, p. 153. 
This story is clearly about how Solomon had many Jinn locked up and put in chains and shackles [en cadenas y en grillos] and under torment. And it says that when Solomon came to death, he ordered that they embalm his body and dress him as if he were alive, and sit him on a royal seat to make it seem to the Jinn that he was alive and not dead. They did as Solomon said, and they put a staff in his hand and fixed on the earth so that he was sturdy in his seat. It says that a worm came out of the earth and ate the staff and Solomon fell to the ground, upon which the Jinn found out that Solomon was dead and they came out of their torment and punishment in which they had been place. ${ }^{45}$

This explanation clearly shows Juan Andrés' knowledge of the tafsir tradition of qurānic exegesis surrounding this verse, including numerous examples that can be traced to such commentaries. For example, the rendering of 'crawling creature of the earth' as a 'worm' is telling, as this appears in many medieval commentaries.

Yet some details are less common in the commentary literature, and the repetition of these odd bits in subsequent works helps us show how Juan Andrés' explanation served as a source for later writers. The number that Juan Andrés gives to this verse offers one such clue. Pérez de Chinchón, in sermon seventeen of his Antialcorano, lists this story of Solomon and the worm although he does not give Juan Andrés' full transliterations. But he certainly relies on Juan Andrés, because even though he also does not call this story 'book three, chapter fourteen', he does give the same group of qurānic references to Juan Andrés in the same order as the Confusión, and in fact he lists all such references as 'book three, chapter nine', the reference Juan Andrés gave for the first Solomon story about the ants, which he told immediately before this story.

Even more telling for tracing the spread of Juan Andrés' version of this story is the detail that Solomon 'ordered that his body be embalmed' and propped up on his staff while sitting in his 'royal seat' in order to deceive the Jinn and

45 'La qual historia quiere dezir más claramente cómo Salomón tenía muchos demonios encarcelados y puestos en cadenas y en grillos y atormentados. Y dize que quando vino Salomón a la muerte, mandó que embalsemassen su cuerpo y que lo vestiessen así como que fuesse bivo, y que lo assentassen en su silla real por dar a enterder [ sic] a los demonios que era bivo y no muerto. Y así lo fizieron como el dicho Salomón mandó y porque estoviesse firme en al silla, posieron una vara en su mano y fincada en la tierra. Dize que salió de al tierra un gusano y comió la vara y así cayó Salomón en el suelo, por la qual cosa supieron los demonios que Salomón era muerto y así salieron del tormiento y de la pena en que estavan puestos'; Juan Andrés, Confusión, p. 153. 
keep them in captivity. Most Muslim commentaries say that he died suddenly while leaning on his staff and no one realized he was dead, but very few discuss his 'seat' or that he ordered himself 'embalmed'. ${ }^{46}$ Yet numerous writers following Juan Andrés repeat this uncommon detail: Lope de Obregón not only reproduces (like Pérez de Chinchón) Juan Andrés' stories about Solomon in the same order, but he also repeats some of Juan Andrés' phrasing, including the detail that he imprisoned many Jinn con cadenas y con grillos de hierro (with chains and with iron shackles), that se hizo enbalsamar (he had himself embalmed), and that he was propped up before a 'worm' ate his staff. Most telling of all is the fact that Lope reproduces Juan Andrés' transliterations almost exactly, and reproduces a few small errors. ${ }^{47}$ Later writers such as Tirso González de Santalla, writing in Latin, and Manuel Sanz in Castilian repeat Juan Andrés' particular details as well, albeit without the transliterations. ${ }^{48}$ Both Sanz and González de Santalla mention Juan Andrés by name and the latter explicitly says that the story is given teste Ioanne Andrae, "by witness of Juan Andrés'.49 Traggia de Santo Tomás de Aquino says explicitly that he con-

46 One exception is the Andalusi exegete al-Qurțubī (d. 1273), who does mention that his body was prepared before death and that he died in his seat. See al-Qurțubī, al-Jāmic li-ậkām al-Qurāān (Beirut: Dār Iḥiyā' al-Turāth al-'Arabī, 1985), on Qur’ān 34:14.

Juan Andrés' transliteration reads: fame delle hun hale meutihi ille debbetu alardi te quulu minceteh faleme harra cebeyeneti alginu aunehun leu quenu y ahlemu algaybeme lebiçu filhad ebi almuhi; Confusión, p. 153. Lope's reads: fame dellehun hale mautihi ille debetu alardi tequulu minçetah faleme hara çebey eneti alginu aunehun leu quenun yahlemun algaybe melebiçu fil hadebi almuli; Confutación, fol. 69v. There is the telling detail of the word 'cebeyeneti' or 'çebey eneti' for what is 'tabayyanati' in the original, both replacing an alveolar 't' sound with a sibilant.

48 Manuel Sanz states, 'como estuviesse dicho Salomon para morir, mando, que le embalmassen y le vistiessen como si estuviera viuo, y assi vestido le pusiesen en un trono o silla Real ... para mayor firmeza, y que no cayesse, le pusieron un baston en la mano, y fixo en tierra, sobre el qual estuviesse apoyado ... hasta que de la tierrra salió un gusano' (Tratado breve, p. 70).

49 González de Santalla states: 'Quinto lib.3 Acorani cap 14 (teste Ioanne Andraea) affirmat, quod Salomon habebat plures Daemones in ergastulo catenis \& compedibus ligatos \& cum morti appropinquavit praecepit, vt cadaver suum vnguentis condirent, \& medicantibus praeservatum in Sella Regia collocarent, vt quasi vivus timeretur. Ita vero fuit executioni mandatum. Caeterum in ipsius dextera virga apposita est, cuius extremitas terrae infixa erat: a qua egrediens vermis virgam corrosit; \& sic Salomon in terrano corruit; \& hoc pacto Daemones cognouerunt, eum esse mortuum \& sic a poenis liberati sunt'; Manuductio, $5 \cdot 32$, p. 545. It is interesting to consider that Santalla's work was translated into Polish in 1694 and book two was later translated into Arabic, thus providing a channel in which knowledge of Juan could be disseminated by Jesuits to Arabic speakers who might otherwise not hear of his story. I am grateful to David Vásquez Ruíz and Emmanuele 
sulted various tafsir writers on what he considers a confusing legend, seeming not to make use of Juan Andrés' text. However, although he then adds a note to his translation conceding that his version differs slightly from Juan Andrés' in some details. He follows this remark with a page-long citation taken verbatim from Juan Andrés' Confusión. ${ }^{50}$

This one case of the death of Solomon shows the long trail of influence left by Juan Andrés' text as it was reused and cited by later Spanish writers. But this impact could also be traced to writers beyond the Iberian Peninsula. It is well known that his work was also printed six times in Italian, as well as in German, French and Latin, and these were followed in the seventeenth century by two more printings in Latin, plus editions in German, English and Dutch. ${ }^{51}$ The English version was cited abundantly by English churchman and orientalist Humphrey Prideaux in his 1697 Life of Mahomet, reprinted as late as $1808 . .^{2}$ Juan Andrés' text - probably in Italian but possibly in Latin - came to Luodovico Marracci, professor of Arabic at Università La Sapienza di Roma, who translated and commented on the Qurân in Latin in 1698. This text was picked up and reprinted in 1721 by Lutheran theologian and biblical scholar Christian Reineccius, who again names Juan Andrés by name and quotes from him

Colombo for bringing this translation - preserved in the Biblioteca Vaticana and as yet unstudied - to my attention. For a general consideration of Santalla's work, see Emanuele Colombo, 'Even among Turks": Tirso González de Santalla (1624-1705) and Islam', Studies in the Spirituality of Jesuits, 44, no. 3 (Autumn 2012): pp. 1-41.

50 Traggia de Santo Tomás notes: ‘Tambien refiere Mahoma en el capitulo 34 el ridículo género de muerte que sufrió Salomon, y aunque está muy confuso en el Alcorán, se puede entender con la ayuda de los Expositores Arabes. Estos dicen, que estando cuidando Salomón de los artífices que tenía empleados en sus obras, le dió tal dolor al vientre, que se recostó sobre el báculo que llevaba, y con la fuerza del dolor quedó muerto pero en estado y figura tan natural que nadie lo conoció. Tampoco se atrevían à acercarse à él, y quedó en esta situacion por un año entero, hasta que un gusano que subió por el báculo lo carcomió de modo, que se quebró el bastón y cayendo entonces el Rey sin movimiento, conocieron estaba muerto. [Note added here]: D. Juan Andrés refiere este suceso con alguna diferencia accidental, diciendo que muchos creen, murió Salomon sentado'; Traggia de Santo Tomás de Aquino, Verdadero carácter, pp. 102-04.

$5^{1}$ On the editions of the text, see the comments of Ruiz García in Juan Andrés, Confusión, pp. 54-56, although one can add more details to her information, such as the existence of a Dutch edition, on which, see Gerard A. Wiegers, review of Confusión o confutación de la secta Mahomética y del Alcorán, in Aljamía, 16 (2004): pp. 254-6o. On the popularity of Juan's work, see also Chapter 8 by Wiegers in this volume. 
directly. ${ }^{53}$ It was referenced by Methodist preacher John Fletcher in 1795 in sermons printed throughout the nineteenth century as late as $1860 .{ }^{54}$ And it was the English translation from $165^{2}$ that made its way to George Sale in 1734, and so Juan Andrés' name came to pass before Thomas Jefferson's eyes and eventually, lay sleeping under the oath-taking hand of Keith Ellison in Washington only a few years ago. Even if Keith Ellison had not taken up Jefferson's Koran, he still may have seen Juan Andrés' name, because Sale's translation is still easily available, having remained in print in England and the United States as late as 1927.

\section{The Appeal of Juan Andrés}

It is possible to get a good sense of the significance of this dissemination by comparing it to a similar work of anti-Morisco polemic written in the same circle of people within only a few years of Juan Andrés' Confusión: Joan Martín de Figuerola's Lumbre de fe contra la secta mahometana y el alcorán (1521). Like Juan Andrés' text, Figuerola's cites abundantly from the Qur'ān. Whereas Juan Andrés only cites a rough, oral transliteration and a Castilian translation of the Arabic text, Figuerola includes original Arabic-script citations of his authorities before then including a transliteration and a translation (Juan Andrés probably intended to include the original Arabic in his text as well, as the text seems to indicate space for it, but the limitations of printing prohibited it, as they would have for Figuerola, had his text been printed). ${ }^{55} \mathrm{~A}$ comparison of the two texts - Figuerola's is still in manuscript in the Real Academia de la Historia ${ }^{56}$ - shows that the texts were part of a shared milieu but were not composed together or by the same authors. They were both produced in the wider region of Valencia, and their works share certain curious details. Figuerola, for example, mentions the same curious story from the Qur'ān that Juan Andrés mentions (based on Qur'ān 36,13-27) about two 'messengers' sent

53 Luodovico Marracci, Alcorani Textus Universus (Padua: [the Seminary Press], 1698). Marracci's comments give evidence of his use of Juan Andrés, such as for example on 58ob81b, ad Sura 36, which can be compared to Juan Andrés, Confusión pp. 214-15 [repr. in Christian Reineccius, Mohammedis Filii Abdallae Pseudo-Prophetae Fides Islamitica, i.e. Al-Coranus (Leipzig: Sumtibus Lanckisianis, 1721), pp. 32-36].

54 For example, John Fletcher, The Works of the Reverend John Fletcher, Late Vicar of Madeley (New York: J. Collord, 1833), vol. 4, p. 227.

On the question of printing Arabic in these polemical works, see García-Arenal and Starczewska, 'The Law of Abraham', pp. 415-16.

$5^{6}$ RAH, ms. Gayangos 1922/36. 
by Jesus to a city (unnamed, but understood to be Antioch), which some exegetes interpreted as referring to Saint Paul. ${ }^{57}$ Figuerola similarly refers to the death of Solomon, depicting it in one of his illustrations. Recently GarcíaArenal and Starczewska have noted a number of similarities between the Qurān citations of Juan Andrés and those found in the Cambridge manuscript of the Latin Qurān produced under the aegis of Egidio da Viterbo, whose work they also show was undoubtedly influenced by Figuerola's. ${ }^{58}$ Figuerola does mention Juan by name on a few occasions and thus certainly must have known of his text.

Nevertheless, in his own work Figuerola himself cites only some of the same qurānic verses as Juan Andrés and I was able to ascertain that their transliterations and translations do not exactly match, suggesting that Figuerola, even if he knew Juan's text, did not copy directly from him on all occasions. Comparing their use of Qur'ān 36,19, for example, Juan Andrés transliterates the Arabic and then paraphrases the story without translating this verse in particular. Figuerola, by contrast, transliterates the verse quite differently and then offers a direct, literal translation. ${ }^{59}$ I have found similar discrepancies for other verses cited by both authors. ${ }^{60}$ Moreover, their statements about the structure

57 RAH, ms. Gayangos 1922/36, fol. 28r-v; and Confusión, pp. 214-15.

$5^{8}$ García-Arenal and Starczewska, 'The Law of Abraham', pp. 433-36. This argument has also been developed in more detail and with more examples by Katarzyna Starczewska in 'No es esto sino hystorias de los antiguos: Between Medieval and Early Modern Narrations in Juan Andrés' Confusión', Medievalia, 18, no. 1 (2015): 217-27. My thanks to the author for sharing this paper ahead of publication.

59 Juan Andrés transliterates the verse thus: $j d$ arcelne jley hi jzneym faque debuhume fahazezne bi çelicin facalu jne jleyquum morcelun; Confusión, p. 214. Martín de Figuerola, by contrast, transliterates the verse thus: Idear slne yllain esnayni essaynifaqueda un hume fabaçanne bielçalixi facalu yne ylaycum murçaluna, and then adds the translation, 'y cuando emviamos a ellos dos y desmentieronlos y ayundamoslos con el tercero y dixeronnos, o vosotros embiados' (fol. 28v). Moreover, Juan Andrés claims the two envoys were either Peter and Matthew or Peter and, and that Muslim commentators state that the 'third' sent to help them was 'Pablo sin duda'; Confusión, pp. 214-15. Figuerola, by contrast states that the first two messengers were Peter and Andrew and that only 'some commentators' suggest that the third was Paul (fol. 28v).

6o For another example of the same verse being transliterated and translated differently, note that Martín de Figuerola cites Qurān 6:38 by saying 'gua mamin debatin filardi guala tibirin yatin brigane aille himamum amcelacum melterrat nefi ylquibabi mizam çunna ilazabiyacxaruna. Y no hay animal en la tierra ni ave bolando con sus alas que no sean resucitados como nosotros'; RAH, ms. Gayangos 1922/36, 16v. Juan Andrés, by contrast, transliterates and translates the same verse differently: 'guame mindebbetinfiler di guale cayrin yatiro gibeneheyhi ille umemun amçeluquum me farratne filquitebi min seyn çumen 
of the text are different. Juan Andrés, as we have seen, claims that the Qurān contains 211 chapters, including 175 in the fourth book, whereas Martín de Figuerola claims 113. These differences suggest that although the latter names Juan Andrés' work, he does not seem to copy directly from him in all cases. A full comparison of both texts remains a scholarly desideratum, pending the publication of an edition of the Lumbre by Elisa Ruiz García. ${ }^{61}$

Although Figuerola's text is more careful and exhaustive in its rendering of Arabic text - both seem to show an influence of oral pronunciation in the norms of transliteration - it was Juan Andrés' text - published at least fifteen times and cited all over Europe for over two centuries - that proved very influential while Figuerola's, never published and leaving no directly discernable impact, at least under its own name, seems to have fallen into the void of history. Why?

Part of this may be chance or luck, and a significant factor was certainly the difference between print and manuscript dissemination - the fact that Figuerola's text was never printed doomed it to obscurity. However, I also believe that another compelling explanation for their different fates is the nature of Juan Andrés' self-presentation: Figuerola presents himself as 'master of holy Theology, acolyte and chaplain of his sanctity, simple beneficiary of the main church of the distinguished city of Valencia'. Juan Andrés, on the other hand, writes from the perspective of a convert and presents his text as a sort of narrative, an unfolding story of conversion and translation. I have analyzed Juan's conversion narrative at length elsewhere, and thus will only briefly summarize his rhetorical strategies here. ${ }^{62}$ Juan not only appeals to the authenticity

ile rabihim yohsarum, que quiere dezir que todas las bestias de la tierra y todas las aves que con sus alas bolan resucitarán en el día del judicio'; Confusión, p. 147. In addition, Figuerola translates Qur'ān 29:46, which he calls 'libro tercero capitulo undecimo', as 'no querais disputar con los que tienen la scriptura', whereas Juan Andrés cites this as 'capítulo noveno, libro tercero ... no queráys disputar con judíos ni con cristianos'; Confusión, p. 221. Also, when Figuerola mentions baptism in commenting on Qurān 2:138, GarcíaArenal and Starczewska note that, similar to Juan Gabriel, he offers the curious translation of 'trincera de Dios'; 'The Law of Abraham the Catholic', p. 431, whereas Juan Andrés does not, calling it only 'bautismo' (p. 9o, p. 214). Each writer, moreover, cites many verses not cited by the other.

61 Access to the manuscript of the Lumbre has proved difficult since Ruiz García announced her plans for an edition in 2003. See Elisa Ruiz García, 'Ante la próxima aparición de dos tratados antialcoránicos: Juan Andrés (1515) y Joan Martín de Figuerola (ms. inédito de la RAH)', Aljamía, 15 (2003): pp. 89-92.

62 For an extended reading of Juan's conversion narrative, see Ryan Szpiech, Conversion and Narrative: Reading and Religious Authority in Medieval Polemic (Philadelphia: University of Pennsylvania Press, 2013), pp. 33-40; and Szpiech, 'Preaching Paul to the Moriscos: The 
of their written authorities, or proof texts, 'the authorities of their own law', but he also makes this appeal through the voice of a convert rather than simply a preacher. The appeal to 'authentic' authorities in their original language is parallel to his appeal to his own conversion narrative, which serves to convince those he calls 'ignorant moors' on the basis of an 'authentic' testimony of a Muslim witness, a 'witness of their nation'. He situates himself as an authority through his use of language and by his references to his own status as a converted alfaquí. ${ }^{63}$ Juan Andrés likens conversion to translation as similar vehicles of proof and appeal in his text. He calls on Muslim readers to heed the words of their own people, both those written in their sacred texts and, more importantly, those spoken by their own intellectual leaders.

Figuerola does occasionally address Muslims directly, saying 'look now my fellow Moor ...' (mira ahora próximo mio de moro...) just as Juan Andrés frequently did. However, Figuerola's use seems to be more that of apostrophe, addressing an absent or imaginary Muslim, whereas Juan seems to use a vocative address to appeal to a real Muslim reader or listener, calling on him in to 'note then, and tell me, Moor ...' (nota pues y dime agora tú, moro...).64 Nevertheless, Juan Andrés' testimonial missionizing strategy - citing texts without insulting or attacking his reader - stands in contrast to Figuerola's approach, in which he also seems willing to adopt, like Cardinal Cisneros, a Duns Scotian position in favor of forced conversion. The manuscript of Lumbre de $f e$ also contains accounts of Figuerola's preaching activities in 1517-18, in the years preceding his commencing work on Lumbre. As he describes, he was asked to take over the work of bishop Martín García who had been ordered by King Fernando to preach four sermons a year to the Muslims of Aragon but who, in his old age, could not fulfill his commitment. ${ }^{65}$ Whereas Juan Andrés claims to have been very well versed in Islamic literature, and in fact claims to have been a principal source of information for the preparation of Martín García's sermons ('which without my work it have been difficult to do'), Figuerola only claims a modest knowledge, gaining after some time in his post

Confusión o confutación de la secta Mahomética y del Alcorán (1515) of 'Juan Andrés', La Corónica, 41, no. 1 (Fall 2012): pp. 317-43.

63 On Juan's status as a converted alfaquí among others such as Juan Gabriel, who participated in the preparation of a Qurān translation commissioned by Cardinal Egidio da Viterbo, see Chapter 7 in this volume by Soto and Starczewska.

64 Cf., for example, Lumbre, fol. 16v, and Confusión, p. 101. On this phenomenon, see here also Chapter 7 .

65 Lumbre, fol. 253, published in Leyendas de José hijo de Jacoby de Alejandro Magno sacadas de dos manuscritos moriscos de la Biblioteca Nacional de París, (ed.) F. Guillén Robles (Zaragoza, 1888), p. lviii. 
'some knowledge of the Qurān and scripture of the said moors'.66 Figuerola, as noted, does mention Juan Andrés by name on a few occasions and seems to rely on his work in various places. Moreover, he notes that the Christians try to preach to and convince 'the most important among them, and if one of them agrees and sees the worth of what they say to him, the others will be easily brought to our faith'. ${ }^{67}$ Naturally, his perspective alone would be less compelling to his audience than that of a former Muslim like Juan Andrés, and he claims to have used the help of convert Juan Gabriel of Teruel ${ }^{68}$ as well as Muslim 'jurists who became Christians' 69

Although Figuerola begins with the intention to speak to the Muslims 'with much love' and not to 'upset them in any way', his mission eventually met with very limited success, and he even admits that he would have been thrown out of the mosque after his first sermon were it not for the influence of Martín García himself. ${ }^{70} \mathrm{He}$ then describes how, in light of this resistance, he adopted more coercive methods: On 26 February 1517, Figuerola threatened his reader with Inquisitorial investigation:

I told them ... that if they did not want to consent by the path of friendship, that the Holy Inquisition and the Pope would quickly open there a bull and commission of the Inquisition against you, so that he who does not conced the truth about his scriptures, that he be punished ... they

66 Juan Andrés claims that he was moved to translate the Qur'ān and hadìth 'por mandado del muy reverendo señor maestre Martín García ... porque en el cargo que tenía de sus Altezas de predicar a los moros podiese, con las auctoridades de su misma ley, confundirlos y vencerlos, lo que sin aquel trabajo mío con difficultad podiera hazer'; Confusión, p. 91. Figuerola, on the other hand, claims that after taking over Martín García's post, 'continué por algún tiempo, por cuanto tenía alguna noticia del alcoran y scriptura de los dichos moros'; Lumbre, fol. 253, printed in Leyendas de José, p. lviii.

67 'los dichos xpianos que tomen a los mas principales dellos que si uno dellos asienta y tiene por bien lo que le dirán, los otros serán facilmente trahidos a nuestra fe'; Lumbre, fol. 253, printed in Leyendas de José, p. lviii.

68 'siendo bien informado ... por uno que se decía maestere Johan Grabiel alfaqui que era de teruel, y ahora, por la gracia de Dios, xpno ... y assí por el dicho informado, fuimos los dos a la dicha festiuidad a su mesquita'; Lumbre, fol. 256, printed in Leyendas de José, p. 1. García-Arenal and Starczewska, 'The Law of Abraham the Catholic', explore this relationship in detail.

69 Figuerola says, 'esto que yo digo lo an scrito alfaquis hechos cristianos'; Leyendas de José, p. lxxv. On this claim, see Chapter 7 by Teresa Soto and Katarzyna K. Starczewska.

'Si no por cedula que lleue del Reverendisimo obispo de barcelona, maestre martín garcía Inquisidor, me echauan de la mesquita, y a mi y a los que conmigo fueron'; Lumbre, fols. 253-54, printed in Leyendas de José, p. lx. 
would make all the Muslim jurists of the kingdom come and in their very own mosques with their books, we would enter into disputation, in order to show how they were lost and outside the path of salvation ... When they saw what I told them and how I was preparing the game in this way, they thanked me again very much for what I said and said that they would be very content to go to the designated place [to debate] and make the most important Muslims come. ${ }^{71}$

Figuerola approaches his Muslim listeners from the agonistic perspective of a Christian polemicist, relying on the help of an informer and threatening his audience with force. The contrast between the different styles and perspectives in the books of Martín de Figuerola and Juan Andrés - the former focusing on linguistic expertise and coercive argument, the latter focusing on an appeal to authenticity based on personal testimony - helps account for the radically different fates of the two works over subsequent years. ${ }^{72}$

It thus comes as no surprise that most writers who cite or mention Juan Andrés also describe him as a convert who represents an 'authentic' witness of Muslim ideas. For example, Bernardo Pérez de Chinchón tells his reader to 'hear of the life of your Muhammad taken from one faqīh of Xàtiva who wrote

71 'Les dixe ... que si por via de amistad no quería en esto consentir, que la Sancta inquisición y del papa se abría y muy presto de una bulla y comissión de Inquisición sobre vosotros, para que no dixesse la verdad de sus escrituras para que sea punido y ... a todos los alfaquis del regno les harian venir, y que dentro de sus mesquitas mismas, con ssus libros, entraríamos en las disputas, para dar a conocer como iuan perdidos y fuera de camino de salvación ... Ellos que vieron lo que les dezia y cómo se preparaba el juego de esta forma, me regraziaron mucho lo que les auía dicho y que ellos eran muy contentos de hir a hun lugar cierto, en el cual ellos arían venir a los moros más principales'; Lumbre, fol. 256, published in Leyendas de José, p. lxv.

72 The different approaches and fates of Juan Andrés and Joan Martín de Figuerola resemble those of an earlier pair of polemical writers from Iberia, the thirteenth-century Catalan Dominican Ramón Martí (d. after 1287) and, a few decades after, the Castilian convert Alfonso of Valladolid (olim Abner of Burgos, d. ca. 1347). Like Figuerola, Martí was a polemicist but not a convert, interested in wielding original source material and not adverse to adopting coercive and violent rhetoric. By contrast, Alfonso of Valladolid, whose project closely resembles Marti's in sources and content, presents his work in a persuasive and largely non-confrontational way, and similar to Juan Andrés, he appeals to his own conversion story in order to establish his authority as an authentic voice of criticism. I explore the rhetorical strategies of these writers in more detail in chapters one and five of Conversion and Narrative. 
it and knew it well. ${ }^{73}$ Similarly, when Lope de Obregón mentions Juan Andrés, he specifies that 'he was Muslim at first' (Juan Andrés que primero fue moro) ${ }^{74}$ All of the writers who used Juan Andrés' text in the subsequent two centuries put a similar stress on his biography and his converted status in particular. ${ }^{75}$ George Sale remarks that Juan Andrés' alleged Qurān translation 'may be presumed to have been the better done for being the work of one bred up in the Mohammedan religion and learning. ${ }^{76}$ A similar pattern of highlighting Juan Andrés' status as a convert from Islam can be found in references to his work from the nineteenth century, ${ }^{77}$ and one even finds references to Juan Andrés' biography in the twentieth in both Christian and Muslim writing. ${ }^{78}$ In 1931, the Islamic Review, the official magazine of the Woking Muslim Mission (a Muslim group that helped disseminate teachings about Islam in the UK in the first half of the twentieth century), copied Sale's description of Juan Andrés and his conversion as part of a history of Qurān translation in the West. ${ }^{79}$ In 1939, the American missionary Samuel Marinus Zwemer referred to 'Johannes Andreas, a native of Xativa in the kingdom of Valencia, who from a Mohammedan doc-

73 'Oyd la vida de vuestro Mahoma sacada de un alfaqui de Xativa que la escrivio y la sabia muy bien'; Pérez de Chinchón, Antialcorán, sermon 15, pp. 256-57.

74 Lope de Obregón, Confutación, fol. 2r.

75 González de Santalla names Juan Andrés as 'Joanne Andrea prius Mahumetano'; Thyrsus Gonçalez de Santalle, Manuductio, p. 66, and states 'fuit hic author prius Maumetanus \& Mahumetanorum Alphaquius seu Sacerdos in Vrbe Xativa', p. 8. Manuel Sanz states, 'assi lo atestigua Juan Andres, que fue alfaqui, o Doctor de la Secta Mahometana, y despues se hizo Christiano y escrivio contra los errorees del Alcoran'; Tratado Breve, p. 4. Manuel de Traggia states that Juan Andrés was 'nacido y criado en la secta mahometana'; Verdadero carácter, p. 15, and when he mentions Juan Andrés' name after this, he usually names him 'Juan andres Alfaqui de Xátiva'.

76 Sale, The Koran, p. vii. Sale qualifies his remark by adding '... though his refutation of that religion, which has had several editions, gives no great idea of his abilities'.

77 For example, see Johann Georg Theodor Grake, Das sechszehnte Jahrhundert in seinen Schriftstellern un ihren Werken (Leipzig: Arnoldische Buchhandlung, 1852), p. 770.

78 For example, Kentuckian writer Thomas De Courcey Osborne (1844-1925), in a brief work from 1910 describing references to Jesus in the Qurān, mentioned Juan Andrés, describing him, in Sale's words, as 'a native of Xativa, Valencia, who, from Mohammedan doctor, became a Christian Priest'. See Thomas De Courcy Osborne, The Koran Christ: Also Mohammedan Memorabilia and Personal Memoranda of Travel (Louisville: Baptist Book Concern, 1910), p. 7 .

79 Khwaja Nizām-u'd-Din Hasan, 'Why Islam is Misunderstood. II. Islam and the West', Islamic Review, 19.6 (1931): pp. 194-217 (at pp. 204-05). 
tor became a Christian priest, translated not only the Koran, but also its glosses and the six books of the Sunna: ${ }^{80}$

Whether or not he was the man he says he was, Juan Andrés represents one of the most influential polemical authors of the sixteenth century, and his popularity and influence - being cited by writers in every century up to the present - must be understood as a product of his rhetoric as much as of his knowledge and sources. Juan Andrés' book was not the most exhaustive or the most punctilious of early modern anti-Muslim treatises, but it was the only such work to present itself as the natural product of an authentic conversion experience. The work of Juan Andrés stands apart from all others of its kind, representing a central node of transmission of medieval polemical thought to the modern world. Although that experience and the real identity of the man who claims to have had it remain elusive and may very well prove to be embellishments of later writers, the work's influence has extended over five centuries, being carried on the spring tide of legend and the appeal of individual testimony and personal confession that became increasingly prevalent in late medieval polemical writing.

8o Samuel Marinus Zwemer, Studies in Popular Islam: A Collection of Papers dealing with the Superstitions and Beliefs of the Common People (London: Sheldon Press, 1939), p. 86. This appears in a summary of 'Translations of the Koran' that was reprinted from an earlier work, found in Samuel Marinus Zwemer, Mohammad or Christ: An Account of the Rapid Spread of Islam in All Parts of the Globe, the Methods Employed to Obtain Proselytes, its Immense Press, Its Strongholds, \& Suggested Means to be Adopted to Counteract the Evil (Edinburgh: Fleming H. Revell, 1916), p. 162. 